\title{
Psychological Impact of Non-therapeutic Circumcision on School Boys
}

\author{
Okul Çağında Erkek Çocuklarda Sünnetin Psikolojik Etkisi
}

\author{
(D) Mete Özkıdık ${ }^{1}$, (1) Zeliha Ersoy Sayın², (1) Alper Coşkun ${ }^{1}$, (1) Mehmet Kazım Asutay ${ }^{1}$, (1) Tuncer Bahçeci ${ }^{1}$, (D) Ali Cansu Bozacı ${ }^{3}$ \\ 1 Şanlıurfa Training and Research Hospital, Clinic of Urology, Şanlıurfa, Turkey \\ 2Şanlıurfa Training and Research Hospital, Clinic of Psychiatry, Şanlıurfa, Turkey \\ 3Şanlıurfa Training and Research Hospital, Clinic of Pediatric Urology, Şanlıurfa, Turkey
}

\section{Abstract}

Objectives: Numerous studies have confirmed high stress levels associated with undergoing an operation in children. In this study we aimed to evaluate perceived stress levels of non-therapeutic circumcision in school boys.

Materials and Methods: One thousand hundred patients aged between 9 and 12 years have been invited to the study. The participants are divided into two groups as circumcised and non-circumcised. Socio-economical level and place of residence are also evaluated. Self administered Turkish Validation of Perceived Stress Scale for Children (PSS-C) was used to assess the perceived stress levels due to undergoing circumcision.

Results: One hundred and twenty-eight patients filled in the questionnare completely. Results confirmed a significantly higher score of perceived stress in circumcised population $(p<0.001)$. There was no correlation with place of residence or socio-economical leve but the younger the patient, the higher the sum score of PSS-C $(p<0.05)$.

Conclusion: Circumcision should be considered as a traumatic experience such as any surgical intervention for pediatric population. Despite religious and social beliefs, patients and parents should be informed about and be conscious of psychological effects of male circumcision.

Key Words: Boys, Circumcision, Perceived Stress, Psychological Trauma

\section{Öz}

Amaç: Çocuklarda ameliyat olmanın ciddi strese yol açtığına dair çok sayıda çalışma bulunmaktadır. Biz bu çalışmada okul çağındaki erkek çocuklarda sünnetin yarattığı algılanan stres düzeyini değerlendirmeyi amaçladık.

Gereç ve Yöntem: Çalışmaya 9 ve 12 yaş arası toplam 1500 hasta çağrıldı. Katılımcılar sünnet olan ve olmayan olarak iki gruba bölündü. Sosyoekonomik düzey ve ikamet yeri de ayrıca değerlendirildi. Çocuklarda Algılanan Stres Düzeyi Ölçeği'nin (PSS-C) Türkçe validasyonu kullanılıp, kendilerinin doldurması şartıyla sünnet olmaya bağlı stres düzeyleri değerlendirildi.

Bulgular: Sünnet, çocukluk çağındaki her ameliyat için olduğu gibi travmatik bir tecrübe olarak görülmelidir. Dinsel ve kültürel değerlere rağmen, hastalar ve ebeveynleri sünnetin psikolojik etkilerinin farkında olmalı ve konu hakkında bilgilendirilmelidir.

Sonuç: Bin yüz yirmi sekiz hasta anketi tamamen doldurdu. Algılanan stres düzeyi sünnetli çocuklarda anlamlı düzeyde yüksek bulundu ( $p<0,001)$. İkamet yeri veya sosyo-ekonomik düzey ile bir ilişki bulunmadı ama çocuklarda yaş azaldıkça PSS-C skorunun arttığı görüldü ( $<<0,05)$.

Anahtar Kelimeler: Erkek Çocuklar, Sünnet, Algılanan Stres, Psikolojik Travma

\section{Introduction}

Circumcision is not performed routinely in most of the countries (1). Most circumcised children are Muslim or Jewish.
Countries that circumcise for non-religious reasons are USA $(2,3)$, Canada, Australia and some countries in the European Union.

Discussion about circumcision has focused on supposed

Address for Correspondence/Yazışma Adresi: Mete Özkıdık MD,

Şanlıurfa Training and Research Hospital, Department of Urology, Şanlıurfa, Turkey

Phone: +90 5321661256 E-mail: meteozkd@gmail.com ORCID ID: orcid.org/0000-0002-7304-9396

Received/Geliş Tarihi: 02.04.2018 Accepted/Kabul Tarihi: 03.05.2018

๑Telif Hakkı 2018 Ankara Üniversitesi Tıp Fakültesi

Ankara Üniversitesi Tıp Fakültesi Mecmuası, Galenos Yayınevi tarafından yayınlanmıştır.

Yayınlanan tüm içerik CC BY-NC-ND lisansı altındadır. 
health factors (3). Authors mostly agree about circumcision in certain cases including antenatal hydronephrosis, recurrent urinary tract infections and vesicoureteral reflux (4). However non-therapeutic circumcision is under debate all over the world.

The main idea to motivate circumcision is prevention from sexually transmitted diseases (STDs) (5). There are several organizations promoting circumcision in Sub-Saharan Africa (6) where AIDS is endemic (7). The typical characteristic of these STD-prevention studies is that almost all of them is designed and performed in endemic areas for several STDs particularly HIV. Generalization of these results to the rest of the world is not a reasonable approach in the era of evidence based medicine.

On the other hand there are also articles in opposition (8-10) that highlight the adverse effects due to circumcision. Conflicting conclusions on male circumcision particularly focus on psychological trauma (11). Researches on circumcision reveal a remarkable degree of pain, possible changes in childmother interaction and castration anxiety (12). The place where circumcision has been performed is also considerable. The typical hospital circumcision, out of view of parents, is a more acceptable approach. However most of the circumcisions are still performed in homes in Şanlıurfa.

Cultural values affect circumcision perspective of populations. As an example, Jewry believe in circumcision because it is mentioned in the Torah. For Muslims, circumcision is a transmitted tradition from their prophet. Therefore it is not possible to determine that Jewry and Muslims practice circumcision substantially for medical reasons. However circumcision trend is motivated by preventive health services in westernalized countries (13). USA is the leading country in this approach with increasing incidence of neonatal circumcision (14).

The neglected and less studied part of circumcision is that of its psychological impact on children. Any elective surgery with conflicting benefits $(15,16)$ such as circumcision should also be assessed of its psychological consequences. But also it is not easy because of the subjectivity of the issue. Thanks to Perceived Stress Scale for Children (PSS-C) which is a valuable and objective test for assessing perceived stress due to surgery, trauma or any other stressors occurring in the last one year; here in this article, we aimed to evaluate the perceived stress due to non-therapeutic circumcision in school boys living in Şanlıurfa (17).

\section{Materials and Methods}

\section{Ethical Statement}

Ethical approval was obtained from the local ethical committee in Şanlıurfa. In addition, all participants and their parents provided their written informed consent.

\section{Study Design}

The study was conducted at Şanlıurfa Research and Training Hospital using a cross-sectional design. A total of 1500 patients aged between 9 and 12 years are invited to participate in the study. Patients who applied to the urology or pediatric urology outpatient clinics between 1 January 2017 and 1 January 2018 were enrolled. Three hundred forty seven patients are excluded owing to having other stressors, being circumcised more than 6 months ago, being a Syrian refugee or undergoing the intervention on non-hygienic conditions. A thousand one hundred and fifty-three participants are divided into two groups as circumcised and non-circumcised. Power analysis showed us that the sample size is sufficient to compare the two groups. (Alpha level: 0.95, p:0.05) Participants in both groups filled in the questionnare on their own to rule out parental effects.

\section{Measurements}

Turkish validation of PSS-C which is was used to determine patient stress level (18). PSS-C is a questionnare designed for children to measure perceived stress due to subjective experiences independent of a specific context. There are two versions of PSS-C determined in the literature. Short version with 9 questions (19) and long version with 14 questions (17) are both reliable enough to evaluate perceived stress in children. Items on PSS-C are rated on a 4-point Likert scale (18) $(0=$ Never, $1=\mathrm{A}$ little, $2=$ Sometimes, $3=\mathrm{A}$ lot). PSS- $\mathrm{C}$ sum scores range from 0 to 27 (18). Cronbach Alfa internal consistency reliability coefficient for The Turkish version of PSS-C is 0.76 (18). The test-retest reliability coefficient is 0.71 (18).

\section{Statistical Analysis}

Means (M) and measures of standard deviations (SD) were calculated for PSS-C sum scores. Sample characteristics were analyzed with independent samples t-test (20). The participants were divided into three groups as $9 \leq 10,10 \leq 11$, $11 \leq 12$ respectively according to age, two groups as high and low according to socio-economic level, two groups as urban and rural according to residency to determine if the perceived stress levels of circumcision vary in different groups. In accordance with current literature, level of significance was set at $p=0.05$ to indicate statistically relevant differences (21). Statistical analyses were performed using the "Statistical Package for the Social Sciences Version 22" (22).

\section{Results}

\section{Sample Characteristics}

Table 1 provides an overview of the characteristics of the study population. Six hundred seventeen (53\%) patients were circumcised and 536 (47\%) non-circumcised. A total of 1128 patients (97\%) answered the questionnare completely. Response rate was slightly higher in non-circumcised group (96\%-99\% 
respectively). Mean age was $10.48 \pm 0.75$ and mean (PSS-C Sum Score) PSSCSS was 7.50 \pm 3.46 .

\section{Determination of Perceived Stress in Study Groups}

Mean age was significantly higher in circumcised group $(10.57 \pm 0.79$ vs $10.39 \pm 0.68 p<0.001)$. Mean PSSCSS was $7.91 \pm 3.64$ (Table 1) in circumcised group whereas $7.03 \pm 3.20$ in non-circumcised group $(p<0.001)$. The association between PSSCSS and age is analyzed by linear regression analysis (23). In both groups as the patients gets older, PSSCSS tend to decrease (Figure 1). Seperate analysis of PSSCSS for three age intervals (Table 1) revealed that mean PSSCSS were higher in circumsized groups for all age intervals and the differences between mean PSSCSS were significant in all age intervals $(p=0.004, p=0.008$, $\mathrm{p}=0.011$ respectively). Figure 2 summarizes the association between PSSCSS and age intervals.
Study population was classified into two groups for place of residence. Table 2 summarizes the characteristics of urbanliving and rural-living groups. 463 (40\%) patients were living in urban areas and $665(60 \%)$ in rural areas. Response rate was slightly higher in urban-living group (99\%, 96\% respectively). There was no significant difference between mean ages (10.48 vs $10.49, p=0.90$ ). Mean PSSCSS was $7.48 \pm 3.43$ in urban group and $7.51 \pm 3.49$ in rural group. The difference was not significant $(p=0.91)$.

Another classification was done due to socio-economic level. Table 3 presents low and high socio-economical groups. Nine hundred and fifty nine (83\%) patients were in the low socioeconomical group and 194 (17) in the high socio-economical group. Response rates were same as $97 \%$ in both groups. There was no significant difference between mean ages $(10.48 \pm 0.75$

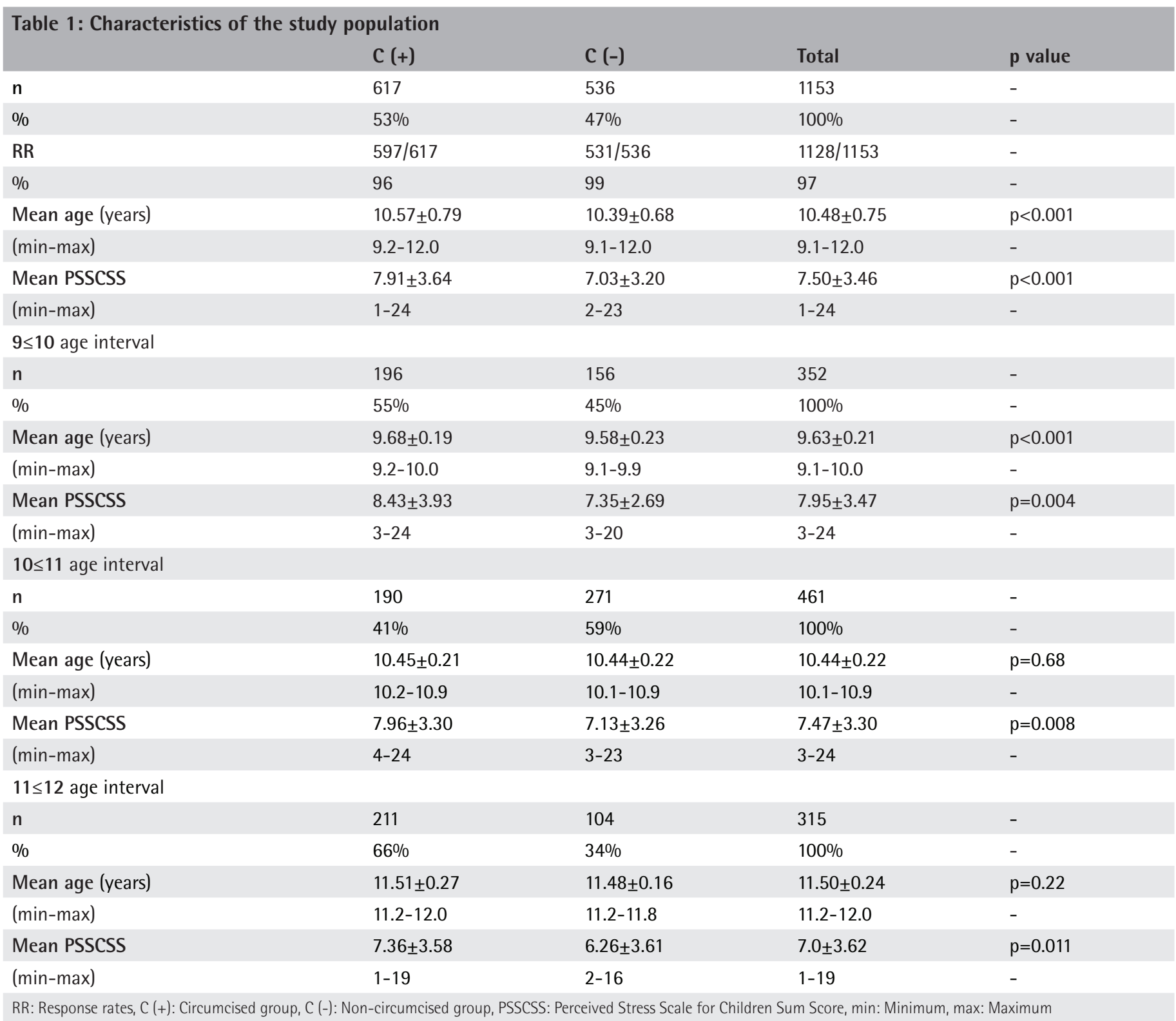




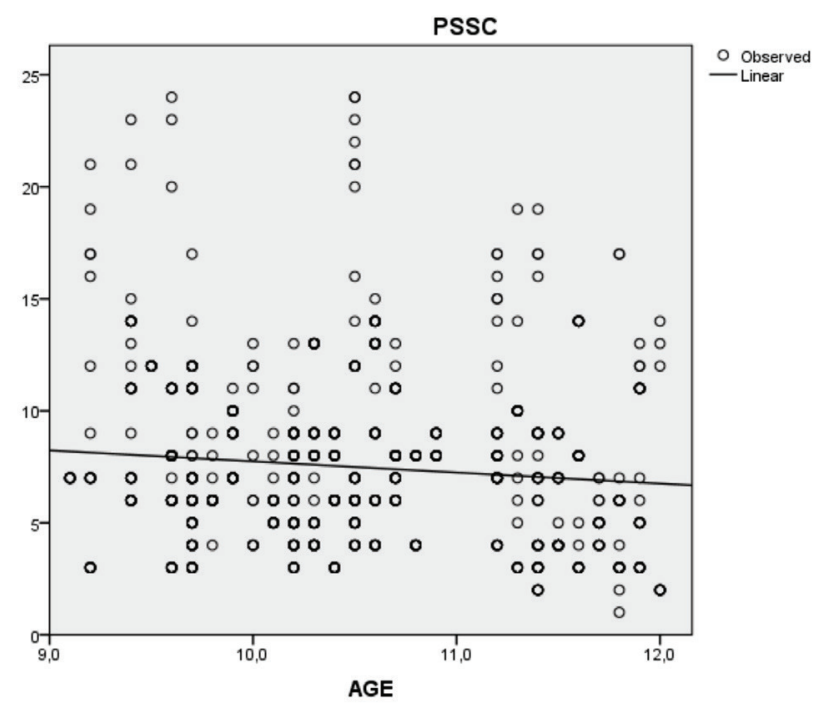

Figure 1: Linear regression analysis of age vs Perceived Stress Scale for Children Sum Score correlation

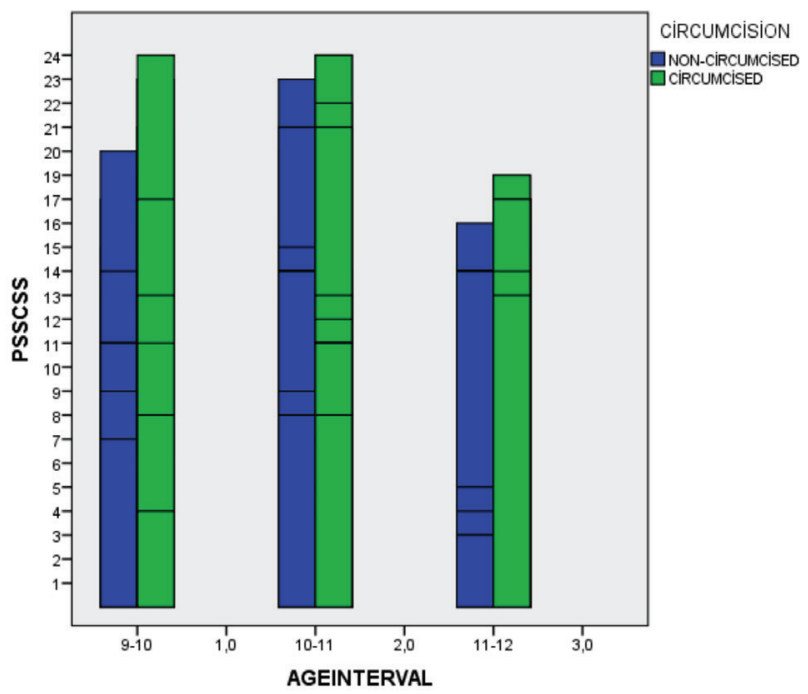

Figure 2: Distribution of Perceived Stress Scale for Children Sum Score according to age intervals

PSSCSS: Perceived Stress Scale for Children Sum Score

\begin{tabular}{lllll}
\hline \multicolumn{4}{|c}{ Table 2: Residency characteristics of the study population } \\
& Urban & Rural & Total & $\begin{array}{l}\text { p } \\
\text { value }\end{array}$ \\
\hline $\mathrm{n}$ & 466 & 687 & 1153 & - \\
\hline $\mathrm{RR}$ & $463 / 466$ & $665 / 687$ & $1128 / 1153$ & - \\
\hline$\%$ & 99 & 96 & 97 & - \\
\hline $\begin{array}{l}\text { Mean age } \\
\text { (years) }\end{array}$ & $10.48 \pm 0.74$ & $10.49 \pm 0.75$ & $10.48 \pm 0.75$ & $\mathrm{p}=0.90$ \\
\hline (min-max) & $9.1-12.0$ & $9,1-12.0$ & $9.1-12.0$ & - \\
\hline Mean PSSCSS & $7.48 \pm 3.43$ & $7.51 \pm 3.49$ & $7.50 \pm 3.46$ & $\mathrm{p}=0.91$ \\
\hline (min-max) & $1-24$ & $2-24$ & $1-24$ & -
\end{tabular}

RR: Response rates, PSSCSS: Perceived Stress Scale for Children Sum Score, min: Minimum, max: Maximum
Table 3: Socio-economic characteristics of the study population

$\begin{array}{lllll} & \begin{array}{l}\text { Low SE } \\ \text { Level }\end{array} & \begin{array}{l}\text { High SE } \\ \text { Level }\end{array} & \text { Total } & \text { p-value } \\ \mathrm{n} & 959 & 194 & 1153 & -\end{array}$

$\begin{array}{llll}\text { RR } & 938 / 959 & 190 / 194 & 1128 / 1153\end{array}$

$\%$

Mean age 97 97 97 (years)

$\begin{array}{lllll}(\min -\max ) & 9.1-12.0 & 9.2-12.0 & 9.1-12.0 & - \\ \text { Mean PSSCSS } & 7.48 \pm 3.33 & 7.59 \pm 3.49 & 7.50 \pm 3.46 & \mathrm{p}=0.68 \\ (\min -\max ) & 1-24 & 2-22 & 1-24 & -\end{array}$

RR: Response Rates, SE: Socio-economic level, PSSCSS: Perceived Stress Scale for Children Sum Score, min: Minimum, max: Maximum

vs $10.49 \pm 0.75, p=0.97$ ). Mean PSSCSS was $7.48 \pm 3.33$ for patients with low socio-economical level and $7.59 \pm 3.49$ for patients with high socio-economical level. The difference was not significant $(p=0.68)$.

On the upshot, mean PSSCSS did not vary significantly in diverse socio-economical levels or residency. Younger age and being circumcised were the risk factors for increased perceived stress levels $(p<0.05)$.

\section{Discussion}

The current study focused on whether circumcision causes a significant stress for children. Studies with PSS-C reveal that PSS-C is easy to be understood by children and also applicable in different samples from several countries. This feature of PSS-C makes it eligible for research. By administrating a valid and objective scale PSS-C, we aimed to contribute to pediatric surgery literature about the issue as well.

The results of the study confirmed a significantly higher perceived stress level for circumcised boys. And also younger boys revealed a higher stress level than olders in accordance with the literature (24).

Şanlıurfa is a non-industrial and low-income city of Turkey so rural-prominent and saliently higher low socio-economical patient ratios were expected. Though various contraceptional methods are performed, the birth rate in Şanlıurfa is the highest one of Turkey with an approximated value of $2.5 \%$. These factors cause children to be circumcised relatively late (generally after age of 12) to the general child population in Turkey. Migration of Syrian refugees gave a rise to the pre-existing economic problems despite government subsidies. According to official records, Syrian refugees make up 25\% of Şanlıurfa's total population. However Syrian refugee children were not included in the study because of having high incidence of psychological disorders caused by the war. 
The traumatic impact of surgery on children is well established in the literatüre $(25,26)$. As an example there are studies reporting long-term psychological effects of tonsillectomy on children $(27,28)$. Also age is an important factor for children to overcome stress of surgery. The younger the child, the higher the risk of psychological trauma due to surgery. The risk-benefit ratio may be in favor of surgery in certain cases, (29) however non-therapeutic circumcision is charged with meatal $(30,31)$ and urethral stenosis (32) in recent studies (33). Therefore, when an elective surgery that have conflicting benefits on children such as circumcision is at issue, we should take attention into psychological impacts of it on children adequately $(34,35)$.

Studies in the current literature are mostly based on subjective fundamentals. According to our point of view, assuming non-therapeutic circumcision as a prophylactic intervention to fight against STDs or religious beliefs of several societies ignore possible psychological impacts of circumcision on children. As physicians, science should be our lodestar and scientific method should guide us to avoid flawed reasoning (36). Certainly science is also influenced by cultural values. But if it is a surgical intervention at issue, we should not regard cultural values as scientific facts in the era of evidence based medicine (37).

Parents should be adequately informed before the procedure. Communication between parents and physicians is mostly insufficient (38). Possible emotional distress about the issue causes a lack of real informed consent. On the other hand in any other surgical intervention, parents almost always query if intervention is essential, what kind of risks or complications are possible. We consider that habitual actions prevail science in these circumstances. Possible phsycological impacts of the procedure should be approved before decision. Fail to appreciate circumcision is a surgical procedure also makes it hard to explain when it comes to apprise any complications due to surgery.

Physician's role in this ritual is also indispensable. Approving parent's decision without any informative comment may lead to adverse psychological consequences. Physician should avoid lack of elaboration and insist on to give sufficient information about the prosedure (39). It should be kept in mind that this is also a medicolegal issue. Psychological impact (40) of circumcision on children might be included in informed consent as a complication.

A single centered study with a cross-sectional design can not present us sufficient evidence to consider certainly that circumcision causes a significant perceived stress. On the other hand, parental perspective is not included in our study but it may be helpful for children to overcome the stress of circumcision in some cases. Also lack of different ethnicities is an obstacle to generalize our results. Randomized controlled studies with larger sample sizes are needed to make a decisive comment.
We aim to point out that circumcision may have pscyhological impacts on children so this should be taken into account before intervention.

\section{Ethics}

Ethics Committee Approval: Ethical approval was obtained from the local ethical committee in Şanlıurfa (no: 2016-079).

Informed Consent: All participants and parents provided a written informed consent.

Peer-review: Internally peer-reviewed.

\section{Authorship Contributions}

Concept: Z.E.S., Design: A.C.B., Data Collection or Processing: A.C., M.K.A., Analysis or Interpretation: M.Ö., Literature Search: T.B., Writer: M.Ö.

Conflict of Interest: No conflict of interest was declared by the authors.

Financial Disclosure: The authors declared that this study received no financial support.

\section{References}

1. Goldman R. The psychological impact of circumcision: BJU International. 1999;83:93-102.

2. American Academy of Pediatrics Task force on circumcision. Technical report: male circumcision. Pediatrics. 2012;130:756-785.

3. World Health Organization and Joint United Nations Programme on HIV/ AIDS. Male circumcision: global trends and determinants of prevalence, safety and acceptability 2007.

4. Kose $E$, Yavascan 0 , Turan 0 , et al. The effect of circumcision on the frequency of urinary tract infection, growth and nutrition status in infants with antenatal hydronephrosis. Ren Fail. 2013;35:1365-1369.

5. Castro JG, Jones DL, Lopez M, et al. Making the case for circumcision as a public health strategy: opening the dialogue. AIDS Patient Care STDS. 2010;24:367-372.

6. Semo BW, Wirth $K E$, Ntsuape $C$, et al. Modifying the health system to maximize voluntary medical male circumcision uptake: a qualitative study in Botswana. HIV AIDS ( Auckl ). 2017;10:1-8.

7. Jones A, Cremin I, Abdullah F, et al. Transformation of HIV from pandemic to low-endemic levels: a public health approach to combination prevention. Lancet. 2014;384:272-279.

8. Sorokan ST, Finlay JC, Jefferies AL. Canadian Paediatric Society, Fetus and Newborn Committee, Infectious Diseases and Immunization Committee. Newborn male circumcision. Paediatr Child Health. 2015;20:311-320.

9. Best K. Male circumcision and HIV risk. Netw Res Triangle Park N C. 1998;18:9.

10. Bowers R. Circumcision does not affect women's STD risk. AIDS Alert 2007;22:124-125

11. Katz J. The question of circumcision. Int Surg. 1977;62:490-492.

12. Ozturk O. Ritual circumcision and castration anxiety. Psychiatry. 1973;36:55.

13. Nelson $C B$, Dunn $R$, Wan J, et al. The increasing incidence of newborn circumcision: data from the Nationwide Inpatient Sample. J Urol 2005;173:978-981.

14. Laumann EO, Masi CM, Zuckerman EW. Circumcision in the United States. JAMA 1997;277:1052-1057.

15. Australian College of Paediatrics. Position statement: routine circumcision of normal male infants and boys. 1996. 
16. Poland RL. The question of routine neonatal circumcision. N Engl J Med. 1990;322:1312.

17. White BP. The Perceived Stress Scale for Children: A Pilot Study in a Sample of 153 Children. Inter J of Pediatr and Child Health 2014;2:1-8.

18. Oral T, Ersan C. Adaptation of the Perceived Stress Scale in Children (811 Years) Into Turkish. Selçuk Üniv Edebiyat Fakültesi Dergisi (SEFAD). 2017;37:419-428.

19. Snoeren $F$, Hoefnagels $C$. Measuring Perceived Social Support and Perceived Stress Among Primary School Children in the Netherlands. Child Ind Res 2014;7:473-486.

20. Kesici T, Kocabas Z. Ankara Üniv Eczacılık Fakültesi Bioistatistik Yayınları 2007;94:209-213.

21. Kim TK. T test as a parametric statistic. Korean J of Anesthes. 2015;68:540546.

22. ICR. IBM SPSS Statistics for Windows, Version 22.0. Armonk, NY: IBM Corp. 2013

23. Kılıç S. Linear regression analysis. Journal of Mood Disorders. 2013;3:90-92.

24. Cansever G. Psychological effects of circumcision. Br J Med Psychol. 1965;38:328.

25. Eth S, Pynoos R. Developmental perspective on psychic trauma in childhood. In Figley C, ed. Trauma and its Wake. New York: Brunner/Mazel, 1985:36-52.

26. Levy D. Psychic trauma of operations in children. Am J Dis Child. 1945;69:22.

27. Lipton S. On psychology of childhood tonsillectomy. Psycoanalitic Study Child. 1962;17:363-417.

28. Jessner L, Blom G, Waldfogel S. Emotional implications of tonsillectomy and adenoidectomy in children. Psycoanalitic Study Child. 1952;7:126-169.
29. Burgu B, Aydogdu O, Tangal S, et al. Circumcision: pros and cons. Indian J Urol. 2010;26:12-15.

30. Berry Jr CD, Cross Jr RR. Urethral meatal caliber in circumcised and uncircumcised males. AMA J Dis Child. 1956;92:152-156.

31. Homer L, Buchanan KJ, Nasr B, et al. Meatal stenosis in boys following circumcision for lichen sclerosus et atrophicus (balanitis xerotica obliterans). J Urol. 2014;192:1784-1788.

32. Santucci RA, Joyce GF, Wise M. Male urethral stricture disease. J Urol. 2007;177:1667-1674.

33. Frisch M, Simonsen J. Cultural background, non-therapeutic circumcision and the risk of meatal stenosis and other urethral stricture disease: Two nationwide register-based cohort studies in Denmark 1977-2013. The Surgeon. 2016;1479:30179-30192.

34. İzi MC. Ethical Evaluation of Non-Therapeutic Male Circumcision. Turk Psikiyatri Derg. 2015;26:204-212.

35. Yavuz M, Demir T, Doğangün B. The effect of circumcision on mental health of children: a review. Turk Psikiyatri Derg. 2012;23:63-70.

36. Kuhn D, Phelps E, Walters J. Correlational reasoning in an everday context. J Appl Dev Psychol. 1985;6:85-97.

37. Timmermans $S$, Angell A. Evidence-based medicine, clinical uncertainty, and learning to doctor. J Health Soc Behav 2001;42:342-359.

38. Patel H. The problem of routine circumcision. Can Med Assoc J 1966;95:57881

39. Briggs A. Circumcision: What Every Parent Should Know. Earlysville, VA: Birth and Parenting Publications. 1985:141.

40. Brown M, Brown C. Circumcision decision: prominence of social concerns. Pediatrics. 1987;80:219. 